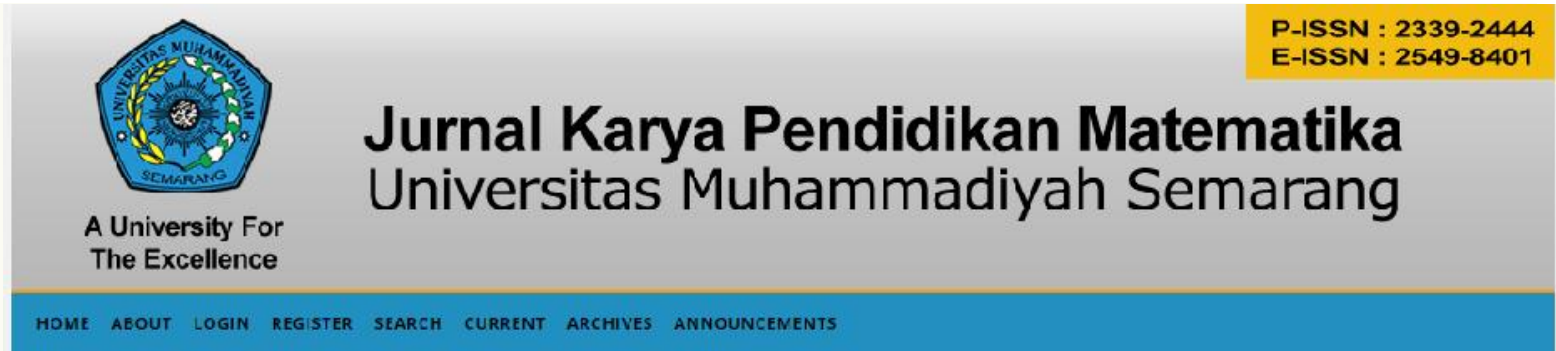

\title{
PENGEMBANGAN MODUL MATEMATIKA BERBASIS MASALAH PADA MATERI SISTEM PERSAMAAN LINEAR DUA VARIABEL
}

\author{
Siti Suprihatiningsih ${ }^{1}$, Pradipta Annurwanda ${ }^{2}$ \\ Dosen Pendidikan Matematika, STKIP Pamane Talino, Landak, Kalimantan Barat \\ Email : ssningsih.math@gmail.com ${ }^{1}$,pradiptamaospati@gmail.com ${ }^{2}$
}

\begin{tabular}{ll}
\hline \multicolumn{2}{l}{ Article history } \\
\hline Submission & $: 2 / 4 / 2019$ \\
Revised & $:-$ \\
Accepted & $: 16 / 4 / 2019$
\end{tabular}

Keyword:

Kata kunci:

Mathematics Module, Problem Solving, Two Variable Linear Equation System.

\begin{abstract}
This study aims to develop a problem-based mathematical module in the material system of two-variable linear equations of class VIII SMP students that are valid, practical and effective. This research is a development research with the method used is ADDIE. The subject of this study was the eighth grade students of SMP Negeri 1 Ngabang, Landak District. The instruments used were validation sheets, observation sheets and student learning outcomes tests. The result indicates that a problem-based mathematical module has been developed in the material system of twovariable linear equations of class VIII SMP students that are valid, practical and effective. Based on the results of the validity test, it can be stated that the problem-based mathematical module produced is valid with a validity value of 79.11. The implementation observation results show that the problembased mathematics module is in the practical category with a practical value of 82.18. Then the results of student learning tests showed that the average value of the learning outcomes test was 83.00 and the effectiveness of the problem-based mathematics module was $87.50 \%$ and included in the effective category. When viewed from the results of the tests performed, the development of problem-based mathematical modules in the subject matter of the two-variable linear equation system has been successfully developed and is suitable for use in Ngabang 1 State Middle School.
\end{abstract}

\section{Pendahuluan}

Matematika menjadi pelajaran yang sangat penting untuk dipelajari dikarenakan matematika dapat digunakan untuk menumbuhkan kemampuan berpikir yang berguna untuk memecahkan masalah dalam kehidupan sehari-hari. Oleh karena itu matematika sudah diajarkan dari jenjang pendidikan sekolah dasar sebagai bekal siswa paling mendasar. Johnson dan Myklebust dalam Sundayana (2013:2) menyatakan bahwa matematika adalah bekal bagi peserta didik untuk berpikir logis, analitis, sistematis, kritis dan kreatif. Selain itu, Heruman (2007:1) menyatakan 
bahwa matematika adalah simbol ilmu deduktif yang tidak menerima pembuktian secara induktif, ilmu tentang pola keteraturan, dan struktur yang terorganisasi dari unsur yang tidak didefinisikan keunsur yang dapat didefinisikan dan kepostulat.

Menurut teori belajar konstruktivisme, siswa harus membangun sendiri pengetahuan di dalam benaknya berdasarkan pengalaman belajar yang telah mereka dapatkan. Dalam hal ini guru bertindak sebagai fasilitator yang membantu siswa dalam mengkonstruksi pemahamannya terhadap suatu materi sehingga mereka mampu memecahkan masalah dalam pembelajaran. Teori tersebut tidak akan tercapai apabila tidak didukung oleh berbagai faktor pendukungnya seperti model pembelajaran yang diterapkan guru di kelas, pemilihan bahan ajar atau modul yang dipakai guru dan lain sebagainya. Pemilihan modul yang menarik dan menyenangkan diharapkan dapat meningkatkan minat siswa dalam belajar sehingga siswa terdorong untuk berperan lebih aktif dalam proses pembelajaran.

Upaya untuk melatih kemampuan pemecahan masalah siswa menjadi sangat penting karena siswa selalu dihadapkan pada berbagai masalah sehari-hari yang harus ditemukan solusi permasalahannya. Oleh karena itu, kemampuan pemecahan masalah merupakan bagian penting dalam mempelajari matematika. Menurut Sumarmo (2014:23) orang yang memiliki kemampuan penyelesaian masalah mampu berpikir analitik dalam mengambil keputusan dalam kehidupan sehari-hari dan membantu meningkatkan kemampuan berpikir kritis dalam menghadapi situasi baru.

Pembelajaran matematika menjadi sesuatu yang bermakna bagi siswa apabila siswa mendapatkan pengetahuan, konsep, dan teori melalui pengalaman praktis dengan cara melaksanakan pemerikasaan, penyelidikan atau bahkan terlibat langsung dalam pembelajaran. Menurut Suyitno (2006:1) pembelajaran adalah upaya menciptakan iklim dan pelayanan terhadap kemampuan, potensi, minat, bakat dan kebutuhan siswa yang beragam agar terjadi interaksi optimal antara guru dengan siswa serta antara siswa dengan siswa. Pemahaman terhadap matematika akan lebih bermanfaat dan berguna ketika siswa dapat mengaplikasikannya untuk memecahkan masalah dalam kehidupan sehari-hari. Siswa tidak cuma cenderung menjawab suatu pertanyaan dengan cara mengutip dari buku atau bahan pustaka lainnya. Namun siswa harusnya dapat lebih menekankan pemahaman kognitif mereka untuk lebih mengembangkan keterampilan berpikir.

Jonassen (2011:28) menjelaskan bahwa terdapat jenis-jenis masalah yang bervariasi, masalah tersebut dibedakan antara masalah well-structure dan illstructure. Masalah well-structure telah diketahui solusi yang dibutuhkan untuk menyelesaikan masalahnya berdasarkan oleh penerapan sejumlah konsep tetap, aturan-aturan, dan prinsip-prinsip. Masalah ill-structure memiliki beberapa solusi unsur yang tidak diketahui, hubungan yang tidak konsisten antara konsep, aturan dan prinsipprinsip.

Berdasarkan observasi awal dan analisis kebutuhan siswa dengan koresponden siswa di SMP Negeri 1 Ngabang Kabupaten Landak, banyak siswa yang menganggap bahwa pelajaran matematika merupakan pelajaran yang cukup sulit dipahami karena bersifat abstrak. Hal tersebut sejalan dengan hasil wawancara terhadap guru matematika bahwa penguasaan materi siswa terhadap pelajaran matematika masih kurang. Menurut keterangan lebih lanjut, hal ini disebabkan oleh minat siswa dalam mempelajari matematika masih kurang. Pembelajaran yang dilakukan oleh guru masih bersifat satu arah dan membuat siswa cenderung pasif. Siswa belum terbiasa dihadapkan pada permasalahan secara langsung dalam kehidupan sehari-hari sehingga hal ini mengakibatkan siswa 
kurang terampil dalam memecahkan suatu masalah.

Tujuan pembelajaran adalah agar siswa berhasil dalam menguasai materi sesuai dengan indikator yang telah ditetapkan sebelumnya. Untuk mewujudkan tujuan tersebut, tentu perlu adanya sumber belajar yang dapat digunakan siswa di kelas. Beberapa komponen pendukung keberhasilan proses pembelajaran di kelas yang salah satunya adalah sumber belajar. Sumber belajar dapat berupa buku, jurnal, Lembar Kerja Siswa (LKS), modul, dan lain-lainnya. Salah satu bentuk sumber belajar dan bahan ajar yang dapat digunakan oleh untuk memfasilitasi siswa memahami materi pelajaran adalah modul. Modul merupakan salah satu bahan ajar yang dapat digunakan untuk memfasilitasi siswa dalam belajar.

Modul merupakan salah satu bahan ajar cetak yang cukup baik digunakan dalam pembelajaran. Menurut Prastowo (2011:106), modul adalah sebuah bahan ajar yang disusun secara sistematis dengan bahasa yang mudah dipahami oleh peserta didik sesuai dengan tingkat pengetahuan dan usia mereka, agar mereka dapat belajar sendiri (mandiri) dengan bantuan atau bimbingan minimal dari pendidik. Menurut Depdiknas (2004) modul adalah bahan belajar yang dirancang secara sistematis sehingga penggunanya dapat belajar dengan atau tanpa seorang fasilitator atau guru. Selain itu, modul adalah sebuah buku yang ditulis dengan tujuan agar peserta didik dapat belajar secara mandiri tanpa arahan atau bimbingan guru. Hal ini menunjukkan bahwa meskipun tidak adanya guru di kelas, modul dapat digunakan siswa secara mandiri dalam belajar. Oleh karena itu pengembangan modul matematika berbasis masalah pada materi pokok sistem persamaan linier dua variabel menjadi cukup penting untuk dilakukan.

Pembelajaran berbasis masalah menekankan pada keterlibatan siswa secara langsung sehingga memungkinkan pembelajaran menjadi lebih bermakna.
Menurut Sudarman dalam Asnila, dkk (2016:1) pembelajaran berbasis masalah adalah suatu model pembelajaran yang menggunakan masalah dunia nyata sebagai suatu konteks bagi peserta didik untuk belajar tentang cara berpikir kritis dan kemampuan pemecahan masalah. Selain itu, Syahrir \& Susilawati (2015:169) menyatakan bahwa modul pembelajaran matematika dengan pendekatan problem based learning sebagai bahan ajar alternatif yang digunakan dalam kegiatan pembelajaran.

Rumusan masalah dalam penelitian ini adalah bagaimanakah mengembangkan modul matematika berbasis masalah pada materi sistem persamaan linier dua variabel siswa kelas VIII SMP yang valid, praktis dan efektif. Oleh karena itu tujuan penelitian ini adalah untuk mengembangkan modul matematika berbasis masalah pada materi sistem persamaan linier dua variabel siswa kelas VIII SMP yang valid, praktis dan efektif.

\section{Metode Penelitian}

Penelitian ini merupakan penelitian pengembangan. Produk yang dikembangkan dan diujicobakan dalam penelitian ini adalah modul matematika berbasis masalah yang valid, praktis, dan efektif pada materi sistem persamaan linier dua variabel (SPLDV) untuk siswa SMP kelas VIII semester 2. Subjek dalam penelitian ini yaitu siswa SMP Negeri 1 Ngabang Kabupaten Landak.

Model pengembangan yang digunakan dalam penelitian ini yaitu ADDIE (Analysis, Design, Development, Implementation, Evaluation). Desain pengembangan yang akan digunakan dalam penelitian ini adalah ADDIE (Analysis, Design, Development, Implementation, Evaluation). Tahapan yang dilakukan dalam pengembangan ini yaitu :

1. Analysis : dilakukan untuk mengumpulkan berbagai informasi sebagai bahan perencaan produk yang akan dikembangkan. Tahapan analisis meliputi analisis kurikulum, analisis siswa dan analisis kebutuhan siswa.

2. Design : menyusun kerangka modul matematika berbasis masalah, peta kebutuhan modul matematika berbasis masalah serta menyusun lembar penilaian. 
3. Development : penulisan draf modul matematika berbasis masalah dan melakukan validasi sebelum diujicobakan.

4. Implementation : mengujicobakan modul matematika berbasis masalah, melaksanakan tes, serta membagikan angket respon.

5. Evaluation : melakukan analisis serta perbaikan terhadap masalah yang terjadi selama pembelajaran.

Instrumen yang digunakan dalam penelitian ini adalah lembar validasi, lembar observasi dan tes hasil belajar. Lembar validasi digunakan untuk memperoleh data tentang hasil validasi para ahli mengenai modul matematika berbasis masalah. Instrumen ini bertujuan untuk mengetahui nilai kevalidan Modul yang dikembangkan berdasarkan aspek kompetensi, isi materi, dan kesesuaian dengan pembelajaran berbasis masalah. Penilaian secara umum tingkat validitas modul matematika berbasis masalah tersebut adalah sangat valid, valid, cukup valid, kurang valid dan tidak valid (Riduwan, 2011:89). Tingkat validitas modul matematika berbasis masalah dalam penelitian ini minimal 41 atau kategori cukup valid.

Lembar observasi digunakan untuk melihat keterlaksanaan modul matematika berbasis masalah yang diperoleh dari masukan peserta didik, kegiatan pembelajaran yang berlangsung, dan masukan dari guru setelah proses pembelajaran. Keterlaksanaan modul matematika berbasis masalah dilihat dari kemudahan penggunaan, keterbacaan, isi, dan bahasa. Penilaian secara umum tingkat praktikalitas modul matematika berbasis masalah menggunakan lembar observasi ini adalah sangat praktis, praktis, cukup praktis, kurang praktis dan tidak praktis (Riduwan: 2011:89). Tingkat praktikalitas modul matematika berbasis masalah dalam penelitian ini minimal 65 atau kategori cukup praktis.

Tes hasil belajar dipergunakan untuk mengetahui persentase ketuntasan hasil belajar siswa. Tes yang digunakan berbentuk pilihan ganda dengan 4(empat) pilihan jawaban sebanyak 25 soal. Indikator yang digunakan pada materi sistem persamaan linear dua variabel (SPLDV) adalah sebagai berikut: 1) siswa mampu menyelesaikan SPLDV dengan metode grafik, 2) siswa mampu menyelesaikan SPLDV dengan metode subsitusi, 3) siswa mampu menyelesaikan SPLDV dengan metode eliminasi, dan 4) siswa mampu menerapkan SPLDV dalam menyelesaikan masalah seharihari. Dari hasil tes akan didapatkan persentase ketuntasan klasikal siswa untuk mengetahui efektifitas modul. Penilaian secara umum tingkat keefektifan modul matematika berbasis masalah adalah sangat baik, baik, cukup, kurang dan sangat kurang (Rizal \& Hermawati, 2017:4). Dalam penelitian ini, modul matematika berbasis masalah dikatakan efektif jika persentase ketuntasan minimal $65 \%$ atau kategori cukup

\section{Hasil Penelitian dan Pembahasan}

Terdapat tiga instrumen penelitian dalam penelitian ini yaitu lembar validasi, lembar observasi dan tes hasil belajar. Instrumen lembar validasi diberikan kepada 3(tiga) orang validator yaitu 2(dua) orang validator ahli materi yaitu guru matematika dan dan 1(satu) validator ahli media yaitu dosen. Untuk lebih jelas, rangkuman hasil instrumen lembar validasi dapat dilihat pada Gambar 1 berikut.

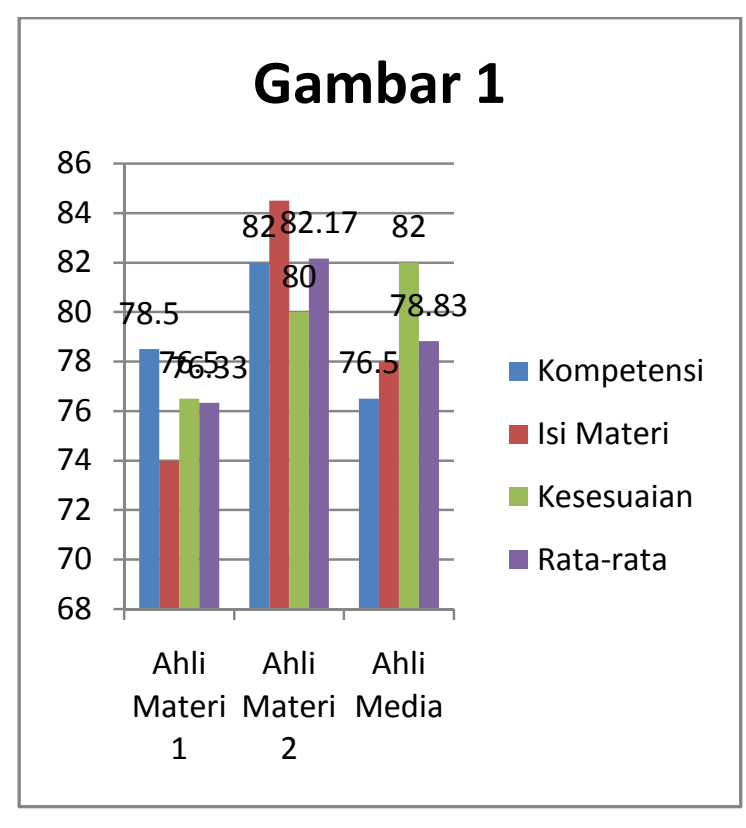

Berdasarkan Gambar 1 diatas, tingkat validitas yang diperoleh dari lembar 
validasi ahli materi pertama sebesar 78,50 yang termasuk dalam kategori valid. Kemudian tingkat validitas yang diperoleh dari lembar validasi ahli materi kedua sebesar 82,00 dan termasuk dalam kategori sangat valid. Selanjutnya tingkat validitas yang diperoleh dari lembar validasi ahli media sebesar 76,50 dan termasuk dalam kategori valid. Rata-rata dari ketiga nilai validator sebesar 79,11 dan termasuk dalam kategori valid. Dengan demikian dapat disimpulkan modul matematika berbasis masalah valid.

Instumen pengumpulan data kedua adalah lembar observasi. Lembar observasi diisi oleh guru dan siswa yang mengikuti pembelajaran pada materi persaman linear dua variabel di kelas. Untuk lebih jelas, rangkuman hasil instrumen lembar observasi dapat dilihat pada Gambar 2 berikut.

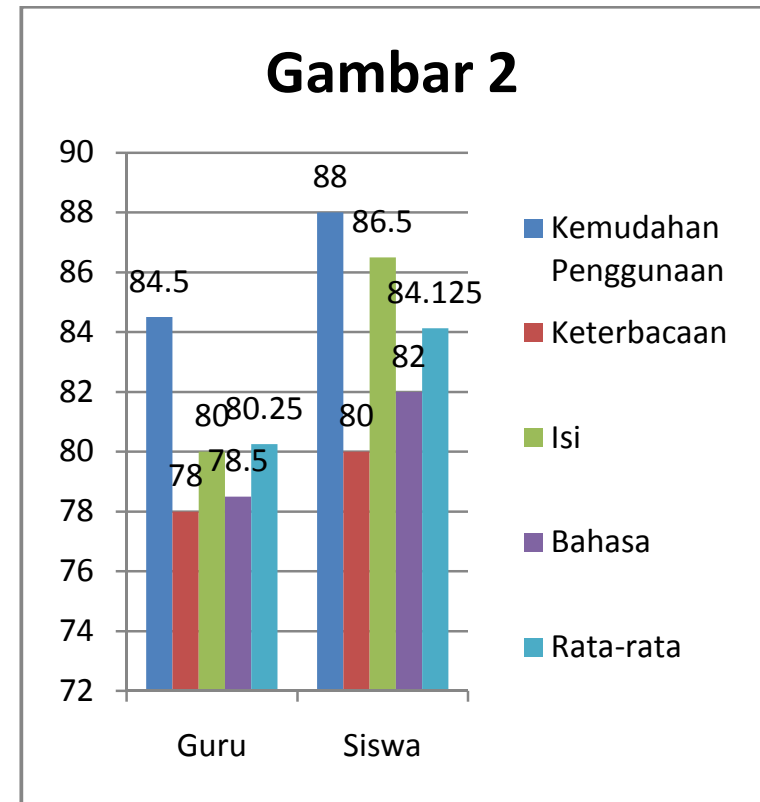

Berdasarkan Gambar 2 diatas, hasil lembar observasi yang diisi oleh guru mendapatkan nilai 84,50 untuk kriteria kemudahan penggunaan, 78,00 untuk kriteria keterbacaan, 80,00 untuk kriteria isi, dan 78,50 untuk kriteria bahasa. Oleh karena itu rata-rata yang diperoleh dari lembar observasi untuk guru adalah 80,25 dan termasuk dalam kategori praktis. Kemudian hasil lembar observasi yang diisi oleh siswa mendapatkan nilai 88,00 untuk kriteria keterbacaan, 80,00 untuk kriteria keterbacaan, 86,50 untuk kriteria isi, dan
82,00 untuk kriteria bahasa. Oleh karena itu rata-rata yang diperoleh dari lembar observasi untuk siswa adalah 84,125 dan termasuk dalam kategori praktis. Rata-rata nilai kepraktisan modul matematika berbasis masalah sebesar 82,18. Dengan demikian dapat disimpulkan modul matematika berbasis masalah praktis.

Instrumen pengumpulan data ketiga adalah tes hasil belajar. Tes diberikan kepada semua siswa yang mengikuti pembelajaran materi persamaan linear dua variabel sebanyak 128 siswa. Untuk lebih jelas, rangkuman hasil instrumen tes hasil belajar dapat dilihat pada Gambar 3 berikut.

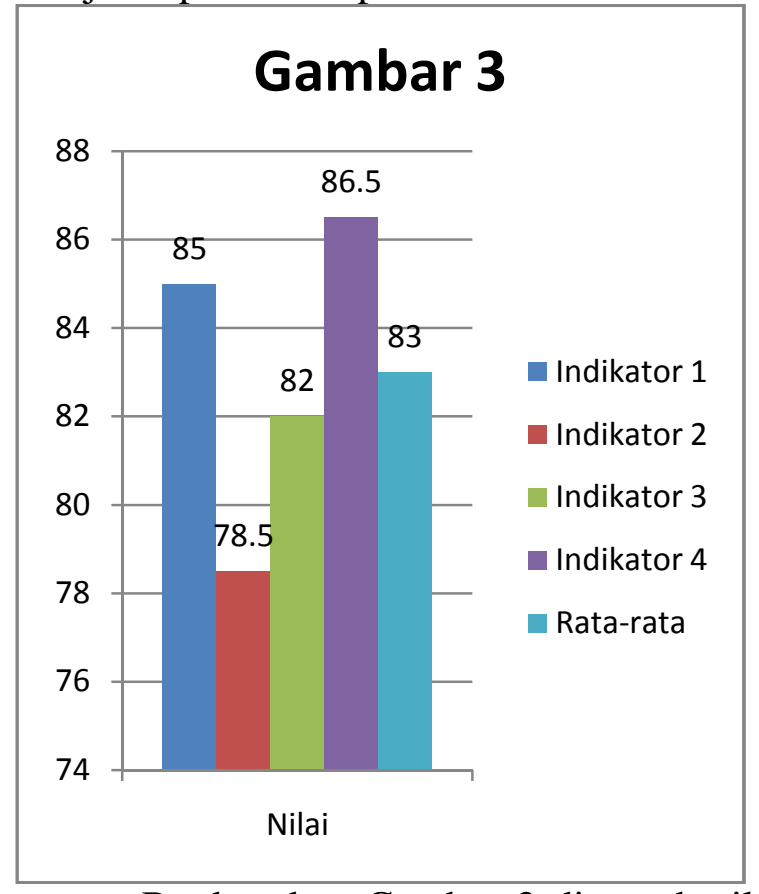

Berdasarkan Gambar 3 diatas, hasil instrumen tes yang telah diisi oleh siswa menunjukkan bahwa nilai rata-rata untuk indikator 1 sebesar 85 , nilai rata-rata untuk indikator 2 sebesar 78,50, nilai rata-rata untuk indikator 3 sebesar 82, nilai rata-rata untuk indikator 4 sebesar 86,50. Kemudian nilai rata-rata untuk semua indikator sebesar 83. Peningkatan hasil belajar ini meyakinkan peneliti untuk mengambil kesimpulan bahwa penggunaan modul matematika berbasis masalah ini dapat meningkatkan hasil belajar siswa. Hal ini sejalan dengan penelitian Anggoro (2015:127) yang menyatakan bahwa penggunaan modul matematika statistika dapat meningkatkan kemampuan berpikir 
kreatif matematis siswa dikarenakan soal yang dikerjakan oleh peserta didik merupakan soal yang didalamnya terdapat indikator untuk meningkatkan kemampuan berpikir kreatif matematis siswa.

Selain itu, keefektifan modul matematika berbasis masalah diperoleh nilai sebesar $87,50 \%$ dan termasuk dalam kategori efektif. Dengan demikian dapat disimpulkan modul matematika berbasis masalah efektif. Hal ini sejalan dengan penelitian Mertayasa (2012:10) yang menyatakan bahwa bahan ajar (modul) matematika dengan berorientasi pada masalah berkontribusi pada peningkatan kemampuan berpikir matematis siswa, serta sebagai salah satu alternatif untuk mengubah paradigma pembelajaran SMP yang berpusat pada guru menjadi berpusat pada siswa. Selain itu, hasil penelitian Citroresmi, dkk (2016:12) menunjukkan bahwa kemampuan penyelesaian masalah dan berpikir kreatif matematis siswa mengalami peningkatan setelah belajar dengan menggunakan modul matematika berbasis masalah.

\section{Simpulan dan Saran}

Simpulan

Penelitian ini merupakan penelitian pengembangan yang menghasilkan modul matematika berbasis masalah. Dalam penelitian ini dapat disimpulkan bahwa telah dikembangkan modul matematika berbasis masalah pada materi sistem persamaan linier dua variabel siswa kelas VIII SMP yang valid, praktis dan efektif. Berdasarkan hasil uji validitas modul matematika berbasis masalah yang telah dilakukan kepada validator dengan beberapa revisi maka dapat dinyatakan bahwa modul matematika berbasis masalah yang dihasilkan sudah valid dengan nilai kevalidan sebesar 79,11. Selain itu, hasil observasi keterlaksanaan menunjukkan bahwa modul matematika berbasis masalah dalam kategori praktis dengan nilai kepraktisan sebesar 82,18. Kemudian hasil tes belajar siswa yang telah memperoleh pembelajaran menunjukkan bahwa nilai rata-rata tes hasil belajar sebesar 83 dan tingkat keefektifan modul matematika berbasis masalah termasuk dalam kategori efektif. Jika dilihat dari hasil uji yang dilakukan maka pengembangan modul matematika berbasis masalah telah berhasil dikembangkan dan layak digunakan di SMP Negeri 1 Ngabang.

Saran

Berdasarkan hasil penelitian dan pengembangan ini, maka dapat disarankan modul pembelajaran matematika hasil pengembangan diharapkan dapat digunakan untuk pembelajaran matematika, sehingga akan mempermudah siswa dalam memahami materi yang disajikan.

\section{Ucapan Terima Kasih}

Kami ucapkan terima kasih kepada Direktorat Penelitian dan Pengabdian kepada Masyarakat, Kementerian Penelitian, Teknologi, dan Pendidikan Tinggi yang telah mendanai penelitian ini dan kami ucapkan terimakasih kepada LPPM STKIP Pamane Talino telah mendukung penelitian ini.

\section{Daftar Pustaka}

Anggoro, Bambang Sri. 2015. Pengembangan Modul Matematika Dengan Strategi Problem Solving Untuk Mengukur Tingkat Kemampuan Berpikir Kreatif Matematis Siswa. Al-Jabar: Jurnal Pendidikan Matematika. Vol. 6, No. 2, Hal: 122-129.

Asnila, Zelmi., Nurrahmawati \& Hera Deswita. 2016. Pengaruh Penerapan Model Pembelajaran Problem Based Learning (Pbl) Terhadap Kemampuan Pemahaman Konsep Matematis Siswa Kelas X SMA N 3 Tambusai. Jurnal Mahasiswa FKIP Universitas Pasir Pangaraian. Vol. 2, No. 2.

Citroresmi, Nindy., Sugiatno., Dede Suratman. 2016. Pengembangan Modul Matematika Berbasis Masalah Untuk Meningkatkan Kemampuan 
Jurnal Karya Pendidikan Matematika Vol 6 No 12019 E ISSN : 2549 - 8401 P ISSN : 2339-2444

Penyelesaian Masalah dan Berpikir Kreatif Matematis Siswa. Jurnal Pendidikan dan Pembelajaran. Vol. 5, No. 4. Hal: 1-14.

Depdiknas. 2004. Pedoman Khusus Penyusunan Modul Sekolah Menengah Atas. Depdiknas. Jakarta.

Heruman. 2007. Model Pembelajaran Matematika di Sekolah Dasar. Bandung: PT Remaja Rosdakarya

Jonassen, D. 2011. Learning to Solve Problem A Handbook for Designing Problem-Solving

Learning Environment

Mertayasa, Dewa. 2012. Pengembangan Perangkat Pembelajaran Matematika Berorientasi Masalah Realistik Untuk Model Pembelajaran Peningkatan Kemampuan Berpikir Sebagai Upaya Meningkatkan Hasil Belajar Siswa Kelas VII. Jurnal Pendidikan dan Pembelajaran Matematika Indonesia. Vol. 1, No. 1. Hal: 1-12.

Prastowo, Andi. 2011. Panduan Kreatif membuat Bahan Ajar Inovatif. Yogyakarta: Diva Press.
Rizal, Afif dan Hermawati, Kuswari. 2017. Pengembangan Game Edukasi Matematika dengan Pendekatan Guided Discovery untuk Siswa Kelas VIII. Jurnal Pendidikan Matematika. Vol.6 No.3 Hal 1-8.

Riduwan. 2011. Belajar Mudah Penelitian: Untuk Guru, Karyawan, dan Peneliti Pemula. Bandung : Alfabeta.

Sumarmo, Utari. 2014. Penilaian Pembelajaran Matematika. Bandung: PT. Rafika Aditama

Sundayana, Rostina. 2013. Media Pembelajaran Matematika. Bandung: Alfabeta.

Suyitno, Amin. 2006. Pemilihan ModelModel Pembelajaran dan Penerapannya di SMA. Semarang: UNNES

Syahrir \& Susilawati. 2015. Pengembangan Modul Pembelajaran Matematika Siswa SMP. Jurnal Ilmiah Mandala Education. ISSN: 2442-9511. Vol. 1, No. 2, Hal: 162-171. 